\title{
The Potential of Human Capital's Development in Russia in the Digital Age
}

\author{
Natalia Alekseeva \\ Institute of Industrial Management, \\ Economics and Trade \\ Peter the Great St.Petersburg \\ Polytechnic University ( $S P b P U)$ \\ St. Petersburg, Russia \\ 0000-0002-7355-3277
}

\author{
Natalia Antoshkova \\ Graduate School of Foreign Languages \\ Peter the Great St.Petersburg \\ Polytechnic University ( $S P b P U)$ \\ St. Petersburg, Russia \\ 0000-0003-3353-3826
}

\author{
Viktor Vasilenok \\ Saint Petersburg National Research \\ University of Information Technologies, \\ Mechanics and Optics (University \\ ITMO) \\ St. Petersburg, Russia
}

\begin{abstract}
In connection with the forecasted purposes of the digital economy`s development in Russia, as well as investments in the human resources' development for digital economy, there is an actual question how much the digitalization of the society and business can increase the efficiency of the human capital's work in the Russian Federation and lead it to the level of European countries. In this regard, the purpose of the following work is to determine the potential of the human capital's development of Russia by 2025 due to the digitalization of its economy. In the following work an indicator of the labour productivity is used as an indicator of the human capital's efficiency. Three scenarios for the digital economy's development of the country are presented. It is shown that with the most optimistic scenario of the digital economy`s development in Russia, the efficiency of the human capital's use has a growth potential by $71.5 \%$ by 2025 compared to the value of the following indicator in 2015 . It was determined that the efficient use of the human capital in Russia by 2025 will exceed the human capital efficiency indicator in Poland in 2015, and will not reach the productivity indicator in such countries as the United Kingdom, Germany, Spain, Italy, France, Sweden by $3 \%$ as of 2015.
\end{abstract}

Keywords-digital economy, digitalization, digital technology, human capital, labour productivity

\section{INTRODUCTION}

Human capital can be represented as investments, that need to be made in human resources to increase economic productivity [1]. A theoretical basis of the human capital's theory Is presented in works of Schultz [2], Sakamota and Powers [3], and Psacheropoulos and Woodhall [4]. The human capital's theory is based on the assumption that education is useful and essential to increase labour productivity of population. According to the work [5], the human capital is considered as an important source of international competitive ability, since the human capital must increase the labour productivity [6].

Russia urgently needs an increase in competitive ability in the international arena [7]. At present, the basis of the gross domestic product is a raw material industry of the economy. Its development potential is limited by the physical volume of natural resources and international prices for raw materials [8]. The greatest development potential in the modern economic system lies in the knowledge economy development [9], knowledge-intensive industries and in the sphere of the business processes digitalization, which development will help to improve the competitive ability of Russia to the maximum extent.

The government of the Russian Federation drew up a national project "Digital Economy", which provides funding for human resources development for the digital economy [10] in the amount of 143.1 billion rubles for the period of $01 / 10 / 2018$ - 31/12/2024. Thus, the major contribution will be made to increase the value of the county`s human capital, which must lead to a growth in the labour productivity and become a source of the international competitive ability. McKinsey Company analysts made a report on the prospects for the digitalization of the Russian economy, where a purpose is indicated: the digital economy`s tripling by 2025 . The following purpose is characterized as ambitious, but achievable.

In [11], it is shown that the human capital is an important aspect of the digital economy, which, through the knowledge aspect, can provide the effective functioning of individual regions and the entire country.

In connection with the forecasted purposes, as well as the investments in human resources' development for digital economy, there is an actual question how much the digitalization of the society and business can increase the efficiency of the human capital's work in the Russian Federation and lead it to the level of European countries. In the following work an indicator of the labour productivity is used as an indicator of the human capital's efficiency [12].

As of 2015, the labour productivity in the Russian Federation was $\$ 52$ thousand per person, and it was the most comparable with the labour productivity in Poland (Fig. 1) among the countries of the world. Theoretically, economy digitalization can significantly increase the labour productivity in Russia, for this reason there is an interesting question what potential for growth has the labour productivity in Russia and what level of human capital's development can digitalization of the Russian economy lead to in comparison with the other countries of the world. In this regard, the purpose of the following work is to determine the potential of the human capital's development of Russia by 2025 due to the digitalization of its economy. To achieve the stated purpose, a forecast of labour productivity in Russia, considering its digital economy`s development up to the year 
2024 and a comparison of the obtained forecast data with the labour productivity`s indicators of other countries were made.

\section{MATERIALS AND METHODS}

The labour productivity indicator depends on the volume of the country`s gross domestic product and a number of working population, engaged in the economy and is determined by the formula.

$$
L P=\frac{G D P_{P P P}}{N W P}
$$

Where LP - labour productivity; GDPPPP - gross domestic product indicator, considering the purchasing power parity; NWP - number of working population.

To forecast the labour productivity, both of these indicators were predicted. However, in order to compare the following results for Russia with the indicators of other countries [13], the values of the gross domestic product were adjusted for the purchasing power parity $[14 ; 15]$. Data for 2016-2108 was obtained from open sources. Forecasting the gross domestic product indicator, considering the purchasing power parity [16], the known values of the gross domestic product and gross domestic product with regard to purchasing power parity for 2016-2108 were used. The calculation was carried according to the following formula:

$$
G D P_{P P P_{j}}=G D P_{j}\left[\frac{1}{3} \sum_{i=2016}^{2018} \frac{G D P_{P P P_{i}}}{G D P_{j}}\right]
$$

Where j - from 2019 to 2024.

The gross domestic products indicators for 2016-2018 are determined according to the data from the Federal State Statistics Service of the Russian Federation. The forecast values of the gross domestic product for 2019-2014 are determined according to the figures provided by the Ministry of Economic Development of the Russian Federation. Indicators of the gross domestic product with regard to purchasing power parity for 2016-2018 are determined according the data from International Monetary Fund.

An average annual number of employed for the period 2019-20124 is determined with the use of the statistical method of correlation and regression analysis based on data on this indicator for the period of 2013-2018, published on the website of the Federal State Statistics Service of the Russian Federation.

Forecast horizon is limited to 2024 inclusively, and it is justified by the period of "Digital Economy" national project's operation and the forecast of the gross domestic product's growth under the influence of the digitalization performed by McKinsey [17].

\section{RESULTS}

The Labor productivity in Russia in comparison with other countries as of 2015 is presented in Fig. 1.

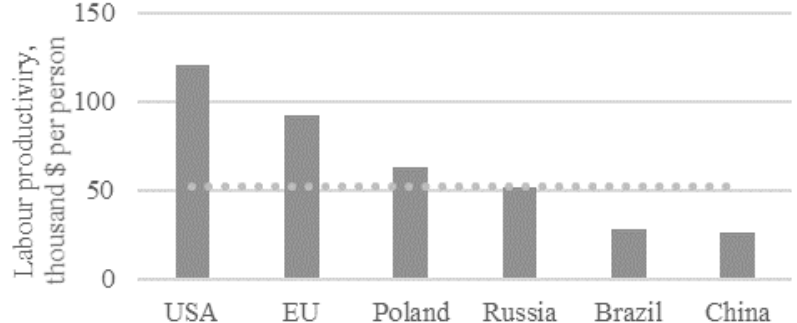

Fig. 1. Labour productivity by countries of the world [17]

To forecast labour productivity data from open sources on gross domestic product and gross domestic product with regard to purchasing power parity was used, the data is presented in Table 1 .

TABLE I. DATA USED FOR FORECASTING

\begin{tabular}{|l|c|c|c|}
\hline Year & $\begin{array}{c}\text { Gross Domestic } \\
\text { Product, bn., } \\
\text { roubles. }\end{array}$ & $\begin{array}{c}\text { Gross Domestic } \\
\text { Product, Considering } \\
\text { the Purchasing Power } \\
\text { Parity, , \$ bn. }\end{array}$ & Inflation \\
\hline 2016 & 86010 & 3887 & $5.4 \%$ \\
\hline 2017 & 92089 & 4027 & $2.5 \%$ \\
\hline 2018 & 103627 & 4213 & $4.3 \%$ \\
\hline 2019 & 109086 & no data & $4.3 \%$ \\
\hline 2020 & 114375 & no data & $3.8 \%$ \\
\hline 2021 & 122234 & no data & $4.0 \%$ \\
\hline 2022 & 130790 & no data & $4.0 \%$ \\
\hline 2023 & 139837 & no data & $4.0 \%$ \\
\hline 2024 & 149488 & no data & $4.0 \%$ \\
\hline
\end{tabular}

To forecast a number of working population, engaged in the economy, the method of correlation and regression analysis was used based on the data from open sources for 2013-2018, presented in Fig. 2.

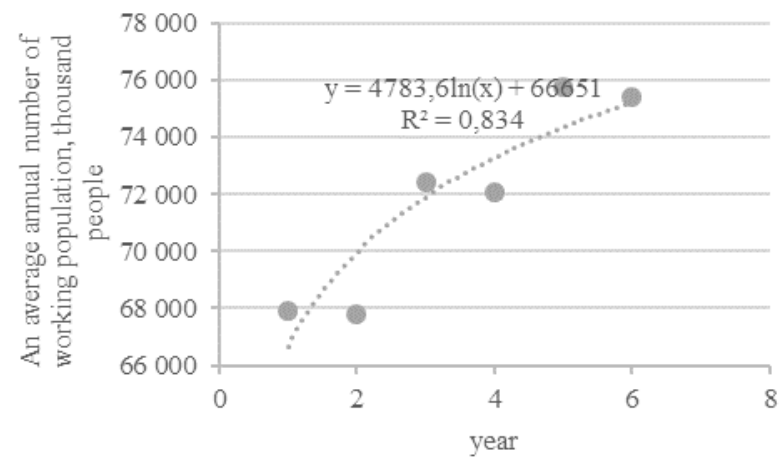

Fig. 2. An average annual number of working population in the Russian Federation in 2013-2018

Forecast of the number of working population, engaged in the economy over a period of 2019-2019, was determined on the basis of the logarithmic trend equation presented in Fig. 2.

Aside from the data from the Ministry of Economic Development of the Russian Federation, McKinsey's 
forecasts were also used to predict labour productivity that provides the possibility of the Russia`s gross domestic product's growth by 2025 due to the digital economy growth by additional $4.1-8.9$ trillion rubles at prices of 2015 . To convert the prices of 2015 to the prices at the end of 2024, an inflation indicator was used, forecasted by the Ministry of Economic Development of the Russian Federation, presented in Table 1. The gross domestic product growth was also adjusted for the purchasing power parity. The adjustment was made according to Formula 2 . The labour productivity at the end of 2024, determined with the use of McKinsey`s forecasts, was obtained with the use of Formula 1 and amounted to US \$85-89 thousand per person. Making forecasts, it was assumed that the labour productivity would be evenly growing from 2019 to 2024 .

Thus, the work presents three scenarios for the forecast growth of the labor productivity in the Russian Federation:

- A baseline scenario, obtained by calculations based on the forecasts of the Ministry of Economic Development of the Russian Federation on the gross domestic product and a number of working population, engaged in the economy, predicted on the basis of data from the Federal State Statistics Service of the Russian Federation.

- A moderately optimistic scenario, obtained by calculations based on McKinsey forecasts for a minimal border of the gross domestic product's growth and a number of working population, engaged in the economy, predicted on the basis of data from the Federal State Statistics service of the Russian Federation.

- An optimistic scenario, obtained by calculations based on McKinsey's forecasts for a maximum border of the gross domestic product's growth and a number of working population, engaged in the economy, predicted on the basis of data from the Federal State Statistics service of the Russian Federation.

Forecast results of the labour productivity growth in the Russian Federation up to the year 2024 inclusively are presented in Fig. 3.

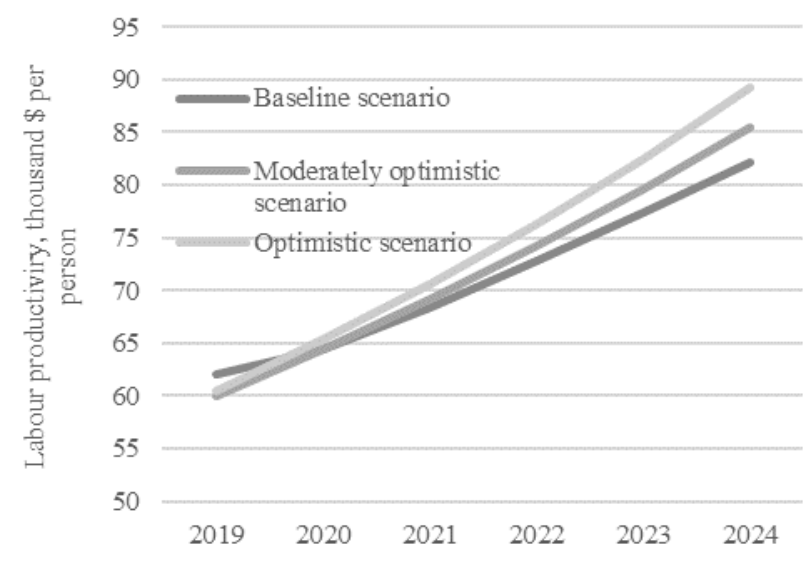

Fig. 3. Forecast of the labour productivity growth in the Russian Federation up to the year 2024

\section{DISCUSSION}

The labour productivity in Russia as of 2015 is inferior to the productivity of such developed countries of the world as the United Kingdom, Germany, Spain, Italy, France, Sweden combined in the graph as the "European Union", and the United States. Poland has the closest productivity indicator, which exceeds Russia`s productivity by $21 \%$.

Investments, the Government of the Russian Federation intends to make in the country`s digital economy, can potentially increase this indicator. The McKinsey Company in its report [17] forecasts a tripling of the digital economy in Russia by the year 2025, stipulating that this is an ambitious, but achievable purpose. According to analysts of this company, a potential economical effect from the digitalization of the Russian economy will increase the country`s gross domestic product by $4.1-8.9$ trillion rubles (in prices of the year 2015).

Analysis of the forecasts presented on the website of the Ministry of Economic Development of the Russian Federation, made it possible to determine that the labour productivity will be estimated at $\$ 82.000$ per person in 2024 . With the implementation of the forecasts about country`s gross domestic product by the year 2025 by $4.1-8.9$ trillion rubles, the labour productivity will be estimated at $\$ 85.000$ 89.000 per person in 2024.

Thus, it can be concluded that the digitalization of the Russian economy will increase the labour productivity indicator in 2025 by $71.5 \%$ in comparison with the value of the following indicator in 2015 if the optimistic scenario of the country`s development will be implemented. That is, the annual increase in productivity improvement in Russia must be $5.5 \%$.

According to the [17] report, the greatest potential for epy digitalization`s increase, and therefore labour productivity, exists in the oil and gas, manufacturing, transportation, chemical and pharmaceutical industries. Construction [18] and health care also have significant growth potential.

Productivity in the amount of $\$ 89.000$ per person exceeds the value of this indicator in Poland only by $3 \%$ and does not reach the productivity indicator in the European Union countries. However, one should not forget that economy digitalization occurs in all countries of the world and will be common to all countries. Thus, it can be said that even optimistic forecasts of the digital economy growth in Russia does not allow it to rise to the European Union`s indicators.

\section{CONCLUSIONS}

The labour productivity in Russia as of 2015, that determines the efficient use of the human capital in the following work, is inferior to the productivity of such countries as the United States, the United Kingdom, Germany and a number of other countries, and it is closer to the Poland's indicator. With the most optimistic variant of the digital economy`s development in Russia, the efficiency of the human capital's use has a growth potential by $71.5 \%$ by 2025 compared to the value of the following indicator in 2015. Thus, the efficient use of the human capital in Russia by 2025 will exceed the human capital efficiency indicator in Poland in 2015, and will not reach the productivity indicator 
in such countries as the United Kingdom, Germany, Spain, Italy, France, Sweden by $3 \%$ as of 2015.

Therefore, Russia has significant potential for the human capital`s development by 2025 due to the digitalization of its economy. However, it should be noted that digitalization is global and allows only to keep up with the development of other countries of the world. Opportunities for the human`s potential development are also laid in the reduction of workplace injuries $[19 ; 20]$, trecking of employees performance [21], a human resource management system`s improvement [22], and creation of the corporate information systems [23].

\section{REFERENCES}

[1] R. E. Ployhart, A. J. Nyberg, G. Reilly, and M. A. Maltarich, "Human capital is dead; long live human capital resources!", J. Jr. of Man., vol. 40, 2013, pp. 371-398. DOI: 10.1177/0149206313512152.

[2] Th. W. Schultz, "Investment in human capital", J. The Am. Ec. Rev., vol. 51, March 1961, pp. 1-17.

[3] A. Sakamota, P. A. Powers, "Education and the dual labour market for Japanese men", J. Am. Soc. Rev., vol. 2, 1995, pp. 222-246.

[4] G. Psacheropoulos, M. Woodhall, Education for Development: An Analysis of Investment, Choice, New York: Oxford University Press, 1997.

[5] A. Kianto, T. Andreeva, and Y. Pavlov, "The impact of intellectua capital management on company competitiveness and financial performance", J. Kn. Man. Res. \& Pr., vol. 11, 2013, pp. 112-122. DOI: $10.1057 / \mathrm{kmrp} .2013 .9$.

[6] A. V. Kozlov, S. S. Gutman, E. V. Rytova, and I. M. Zaychenko, "The application of the fuzzy sets theory to valuing cumulative labor potential of the region", IEEE Int. Conf. on Soft Comp. and Meas. pp. 621-623, May 2017. DOI: 10.1109/SCM.2017.7970668.

[7] N. Didenko, S. Kulik, D. Skripnuk, and E. Samylovskaya, "A country competitiveness analysis. Adl-model involved", International Multidiscip. Sci. Geo. Conf. Surv. Geol. and Min. Ec. Man., SGEM, Bulagaria, vol. 18, pp. 3-10. DOI: 10.5593/sgem2018/5.3/S28.001

[8] I. A. Rudskaya, D. G. Rodionov, "Comprehensive evaluation of Russian regional innovation system performance using a two-stage econometric model", Espacios, vol. 39, 2018.

[9] A. V. Kharlamov, T. L. Kharlamova, and O. S. Koroteeva, "Development of the educational system and the priorities of the knowledge economy", 30th Int. Bus. Inf. Man. As. Conf, IBIMA 2017 - Vision 2020: Sust. Ec. Dev., Inn. Man., and Gl. Gr., Spain, pp. 4270-4277, November 2017.

[10] T. V. Kuladzhi, A. V. Babkin, and S. - A. Yu. Murtazaev," Enhancing personnel training for the industrial and economic complex in the conditions of the digital economy", IEEE 6th Forum Str. Part. of Univ. and Ent. of Hi-Tech Br. (Sci. Educ. Innov.), SPUE, 2017.
[11] T. A. Korneeva, O N N Potasheva, T. E. Tatarovskaya, G. A. Shatunova, "Human capital evaluation in the digital economy," Advances in Intelligent Systems and Computing, 2019, vol. 908, pp. 66-78.

[12] O. Y. Kogut, R. E. Janshanlo, K. Czerewacz-Filipowicz, "Human capital accounting issues in the digital economy," Advances in Intelligent Systems and Computing, 2019, vol. 908, pp. 296-305.

[13] H. Ragoubi, S. El Harbi, "Entrepreneurship and income inequality: a spatial panel data analysis," International Review of Applied Economics, 2018, vol. 32(3), pp. 374-422. DOI: 10.1080/02692171.2017.1342776.

[14] M. Bahmani-Oskooee, S.W. Hegerty, "Purchasing power parity in less-developed and transition economies: A review paper," Journal of Economic Surveys, 2009, vol. 23(4), pp. 617-658. DOI: 10.1111/j.1467-6419.2009.00574.x.

[15] L. Achy, "Parity reversion persistence in real exchange rates: Middle income country case," Applied Economics, 2003, vol. 35(5), pp. 541553. DOI: $10.1080 / 0003684022000015937$

[16] A. Deaton, A. Heston, "Understanding PPPs and PPP-based national accounts" J. Am. Ec. Jr.: Macroec., vol. 2, pp. 1-35, October 2010.

[17] A. Aptekman, Digital Russia: new reality", "Цифровая Россия: новая реальность", 2017, p. 134.

[18] N. Alekseeva, N.Antoshkova, S.Pupentsova, "Application of the Monte-Carlo Simulation Method in Building and Energy Management Systems", Adv. in Int. Syst. and Comp., vol. 983, pp. 257-266 (2019), December 2018. DOI: 10.1007/978-3-030-19868$8 \_26$.

[19] I. I. Kovalenko, A. S. Sokolitsyn, and V. P. Semenov, "Industrial injuries in the socio-economic aspect", 3rd Int. Conf. Ergo-2018: Hum. Fact. in Compl. Tech. Sys. and Env., Russia, pp. 205-208, July 2018

[20] I. Bagaeva, O. Iliashenko, A. Borremans, "Theoretical and methodological aspects of the competence approach to the evaluation of the organization's personnel", Int. Sc. Conf. Envir. Sc. for Con. Ind., ESCI 2018, vol. 193, no. 05060, March 2018. DOI: $10.1051 /$ matecconf $/ 201819305060$

[21] I. Ilin, S. Shirokova, and A. Lepekhin, "IT solution concept development for tracking and analyzing the labor effectiveness of employees", J. Web of Conf., vol. 33, March 2018. DOI: $10.1051 / \mathrm{e} 3$ sconf/20183303007.

[22] A. R. Bril, O. V. Kalinina, and I. V. Ilin, "Economic analysis of projects in the improvement of the HR management system of enterprises", 29th Int. Bus. Inf. Man. As. Conf. - Ed. Exc. and Innov. Man. through Vis. 2020: From Reg. Dev. Sust. to Gl. Ec. Gr., Austria, pp. 2268-2277, May 2017

[23] E. Yu. Vinogradova, S. L. Andreeva, A. V. Babkin,and A. I. Galimova, "Corporate information system - Element of efficient human resources management of the industrial-economic complex", IEEE, 6th Forum Str. Part. of Univ. and Ent. of Hi-Tech Br. (Sci. Ed. Inn.), SPUE, 2017. 